\title{
Lipomatous tumours in adrenal gland: WHO updates and clinical implications
}

\author{
Alfred King-yin Lam \\ Cancer Molecular Pathology, Menzies Health Institute Queensland and School of Medicine, \\ Griffith University, Gold Coast, Australia
}

Correspondence should be addressed to A K-y Lam

Email

a.lam@griffith.edu.au

\begin{abstract}
Adrenal lipomatous tumour is a group of adrenal tumours with a significant component of adipose tissue. According to the current World Health Organization (WHO) classification of tumours of endocrine organs, adrenal myelolipoma is the only entity amongst the group of tumours being described. In the literature, other more recently documented adrenal lipomatous tumours included 24 lipomas, 32 teratomas and 16 angiomyolipomas. Rare fatty tumours of the adrenal gland comprised liposarcoma, hibernoma, adrenocortical tumours with fat component and rare adrenal tumours with fat component. Myelolipoma comprises approximately $3 \%$ of primary adrenal tumour. It is noted more commonly in females and in the right adrenal gland. Approximately 40 bilateral myelolipomas were reported. The tumour is most frequently recorded in patients between fifth and seventh decades of life. Adrenal lipomas are often seen in males and in the right adrenal gland. They were commonly noted in patients in the sixth decade of life. The diagnosis could only be possible on examination of the surgically removed specimen. Adrenal teratomas were more common in females and with a bimodal age distribution. Slightly over $60 \%$ of the patients with adrenal teratoma are symptomatic. Adrenal angiomyolipomas were often symptomatic, more common in females and in the fifth decades of life. To conclude, adrenal lipomatous tumour is uncommon. They are often benign and non-functional. It is important to recognize the features of this group of lipomatous tumours in the adrenal gland as they are being detected on increasing incidence as a result of the wide-spread use of modern imaging modalities.
\end{abstract}

\author{
Key Words \\ - lipomatous \\ - adrenal \\ - myelolipoma \\ - lipoma \\ - teratoma \\ - angiomyolipoma
}

\section{Introduction}

Adrenal lipomatous tumour is defined as a group of adrenal tumours with a significant proportion of adipose tissue. Only two large series of adrenal lipomatous tumours were noted in the literature (Lam \& Lo 2001, Zhao et al. 2014). In the past, adrenal lipomatous tumours were often detected at autopsy. In the recent years, they were detected as fat-containing adrenal incidentaloma by ultrasonography, computerized tomography (CT) or magnetic resonance imaging (MRI) as well as functional imaging such as positron emission tomography (PET).
Myelolipoma is the most common type of adrenal lipomatous tumours. In the 4th edition of World Health Organization (WHO) classification of tumours of endocrine organs, adrenal myelolipoma is the only entity amongst the group of tumours being described (Lam et al. 2017). Apart from adrenal myelolipomas, there is lack of information of the other adrenal lipomatous tumours. These adrenal lipomatous tumours were often reported as case reports in the literature. They are relatively recently described in the literature when compared to myelolipoma. To date, there

Published by Bioscientifica Ltd 
is no review in literature on this group of adrenal tumours in the literature. In this review, the currently available data on the epidemiological, clinical and pathological aspects of this group of adrenal disease were presented. Particular emphases were put on the adrenal lipomatous tumours other than myelolipomas as they have not been covered in the current WHO classification.

\section{Myelolipoma}

The most well-known adrenal lipomatous tumour is adrenal myelolipoma. Myelolipoma is the second most common adrenocortical tumour and the most common adrenal lipomatous tumour (Lam 1992, Lam $\&$ Lo 2001). It is a benign tumour in the adrenal cortex composed of mixture of adipose tissue and bone marrow (haematopoietic) elements. In large series, adrenal myelolipoma comprises approximately $3-4 \%$ of primary adrenal tumour (Lam \& Lo 2001, Kulis et al. 2012, Shenoy et al. 2015).

In 2017s edition of World Health Organization (WHO) classification of tumours of endocrine organs, adrenal myelolipoma is classified as mesenchymal and stroma tumour in the adrenal cortex (Lam et al. 2017). In this edition, when compared to the previous edition, the epidemiology, localization, clinical features, macroscopy, histopathology, genetic profile, prognostic and predictive factors of the tumour were updated. These updates were included in the following sections.

In the literature, Arnold recorded the earliest documented case of adrenal myelolipoma as 'adrenal lipoma' in German literature in 1866 (Arnold 1866). Then, Edgar von Gierke, a German pathologist, reported the fatty component and myeloid component in 1905 (Gierke 1905). The name 'myelolipoma' was first coined by 1929 by a French pathologist, Charles Oberling (Oberling 1929).
The fat component of adrenal myelolipoma was postulated to be derived by the mesenchymal stem cells of stromal fat of adrenal cortex (Feng et al. 2013). The mature adipocytes then stimulate factors to recruit circulating haematopoietic elements to the site.

The metaplasia occurs in response to stress related to stimuli such as necrosis, infection, stress or trauma. The stress may be related to prolong increase in endogenous adrenocorticotropic hormone (ACTH) stimulation (Shenoy et al. 2015). Myelolipoma has been reported to be associated with many diseases as it was commonly being detected incidentally during workup for other diseases. In some adrenal myelolipomas, they were detected in patients with chronic diseases such as cancers and diabetes mellitus. In these conditions, endogenous ACTH could be elevated. It is of interest that some adrenal myelolipomas were associated with haematological diseases in which haemolytic anaemia or ineffective erythropoiesis is present (Au et al. 2000, Motta et al. 2016). These haematological conditions could contribute to the presence of extramedullary haematopoiesis that was postulated to trigger the myeloid component in adrenal myelolipoma.

More than 1200 cases of adrenal myelolipomas were reported in the literature with more than $75 \%$ of the cases reported after 2000 (Shenoy et al. 2015). The increase in incidence of reporting the entity in the recent years is assumed to be due to the increased use of imaging modalities. Adrenal myelolipomas have been reported in a few larger series (Table 1) (Lam \& Lo 2001, Castillo et al. 2007, Gershuni et al. 2014, Yin et al. 2014, Zhao et al. 2014). The tumour is more commonly reported in females (Table 1) (Yin et al. 2014, Zhao et al. 2014). It is most often noted in patients between fifth and seventh decades of life with an average age at presentation in the sixth decade of life. There is a wide age range at presentation from 16 months to 84 years (Lam \& Lo 2001, Hsu et al. 2012,

Table 1 Features of large series of adrenal myelolipoma in the literature.

\begin{tabular}{|c|c|c|c|c|c|c|c|c|}
\hline $\begin{array}{l}\text { Author/yearl } \\
\text { country }\end{array}$ & $\begin{array}{l}\text { Period } \\
\text { (year) }\end{array}$ & No & Sex ratio & Age (range) (year) & Side & Size $(\mathrm{mm})$ & Weight (g) & Presentation \\
\hline Lam/2001/HK & 30 & 11 & $8 \mathrm{M}: 3 \mathrm{~F}$ & $62(41-81)$ & $6 \mathrm{R}: 5 \mathrm{~L}$ & $43(4-145)$ & $141(4-1018)$ & Sym. $=1 ;$ Asym. $=10$ \\
\hline Castillo/2007/Chile & 7 & 18 & $12 \mathrm{M}: 6 \mathrm{~F}$ & $54(35-75)$ & 16R:2L & $86(45-140)$ & - & - \\
\hline $\begin{array}{l}\text { Gershuni/2014/ } \\
\text { USA }\end{array}$ & 17 & 16 & 6M:10F & $54(33-76)$ & 7R:9L & $84(25-210)$ & - & - \\
\hline Zhao/2014/China & 31 & 65 & 21M:44F & 52 & 41R:22L:2B & 62 & 33.5 (15.5-1750) & Sym. = 53; Asym. = 12 \\
\hline Yin/2014/China & 10 & 40 & $15 \mathrm{M}: 25 \mathrm{~F}$ & 53 & 31R:9L & 50 & - & Pain $=17 ;$ no pain $=23$ \\
\hline Total & - & 150 & 62M:88F & - & 101R:47L:2B & - & - & $\begin{array}{l}71 \text { symptomatic; } \\
45 \text { asymptomatic }\end{array}$ \\
\hline Average & - & - & - & $53(33-81)$ & - & $63(4-210)$ & $49(4-175)$ & - \\
\hline
\end{tabular}

Asym., asymptomatic; F, female; L, left; M, male; R, right; Sym., symptomatic; -, not available. 
Barman et al. 2014). Also, it is twice more frequently seen in right adrenal gland as compared to the left (Table 1).

In the English literature, approximately 40 cases of bilateral myelolipomas were noted (Jung et al. 2007, Yang et al. 2015, Zattoni et al. 2015, Kale et al. 2015, Chakraborty et al. 2016, Soveid \& Rais-Jalali 2016). Shenoy and coworkers analysed the literature and reported that $12 \%$ of cases reported in the literature are bilateral (Shenoy et al. 2015). This may be related to the bias in reporting cases of bilateral myelolipomas. From the pooled results of some large series in the literature, approximately $1 \%$ of adrenal myelolipomas were bilateral (Table 1). Recently, Zattoni and coworkers have reviewed the literature of bilateral adrenal myelolipomas (Zattoni et al. 2015). The authors noted that the average age of the 19 patients with bilateral adrenal myelolipomas was 46 years (range 24-69) with an equal sex ratio (9 males and 10 females). Bilateral adrenal myelolipomas often associated with hormonal dysfunctions such as in congenital adrenal hyperplasia, Cushing disease (with pituitary adenoma) and hyperaldosteronism (Jung et al. 2007, Kale et al. 2015, Chakraborty et al. 2016, Soveid \& Rais-Jalali 2016).

On review of the literature, Shenoy and coworkers reported that adrenal myelolipoma comprised $6 \%$ of adrenal incidentaloma detected on radiological examination (Shenoy et al. 2015). For the symptomatic cases, the symptoms reported are often abdominal pain or discomfort. Occasionally, adrenal myelolipoma may present with symptoms and signs of acute abdomen as a consequence of complications (e.g. haemorrhage, rupture and abscess) (Kumar et al. 2015).

Biochemically, majority of the adrenal myelolipomas were non-functional. In the literature, endocrine dysfunction was noted in 7\% of adrenal myelolipoma (Shenoy et al. 2015). A couple of cases were associated with hormonal manifestations such as excessive steroid (Cushing's syndrome), aldosterone (Conn's syndrome), sex hormones and catecholamines secretions (Tamidari et al. 2006, Udupa et al. 2012, Su et al. 2014, Shenoy et al. 2015). The hormonal manifestations disappeared after resection of these myelolipomas. The cause of the hypersecretion is largely unknown but may be due to mechanical irritation of the adrenal myelolipoma. Also, hyperthyroidism was noted in 51-year-old woman with adrenal myelolipoma (Ide et al. 2007). In this case, the cells in the myelolipoma expressed thyroid hormone receptor. In addition, many myelolipomas are noted in patients with congenital adrenal hyperplasia (Soveid \& Rais-Jalali 2016). The condition accounted for nearly half
A

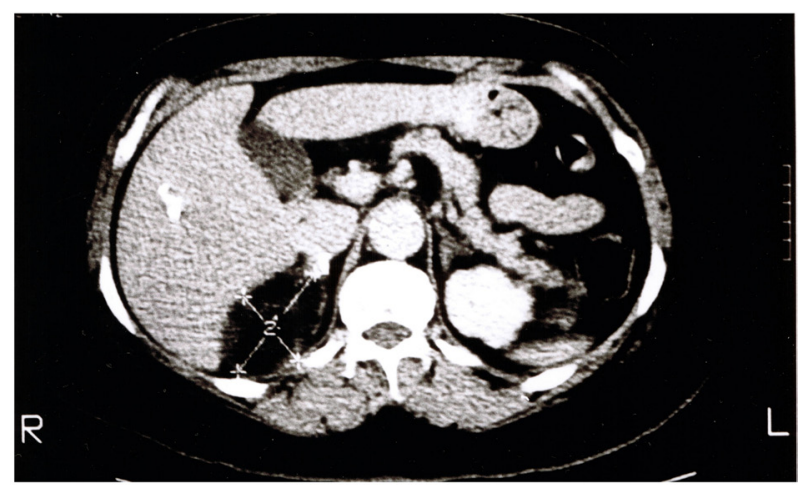

B

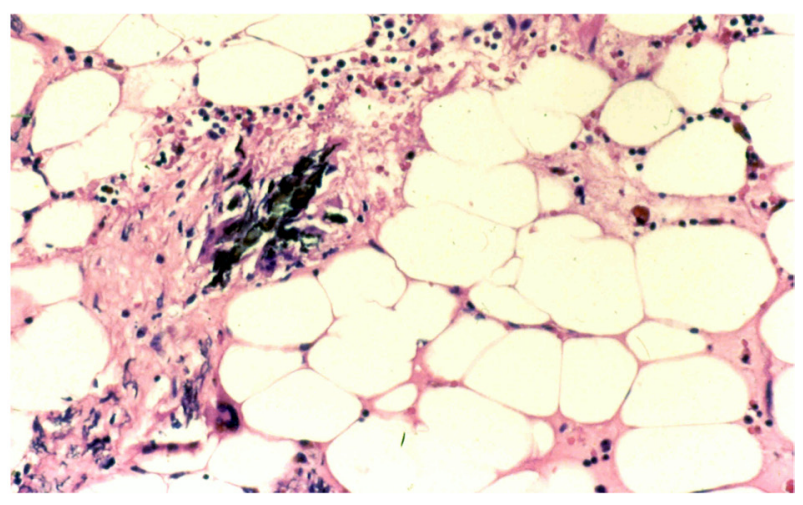

Figure 1

Adrenal myelolipoma. (A) CT scan showing a well-demarcated hypodense mass (cross arrows) in the right adrenal region. (B) Microscopic features of myelolipoma showing the presence of adipose tissue mixed with bone marrow cells of red blood cell and white blood cell lineages noted.

Calcification is noted in fibrous stroma (haematoxylin and eosin $\times 40$ ).

of the adrenal myelolipomas with endocrine dysfunction (Shenoy et al. 2015). The aetiology could be secondary to chronic stimulation of the adrenals by adrenocorticotropic hormone (ACTH).

Radiological examination of adrenal myelolipoma reveals a hypodense mass consistent with the presence of adipose tissue (Fig. 1A). Pre-operative diagnosis could be obtained by fine needle aspiration. The presence of cells of myeloid series with interspersed adipocytes in fine needle aspiration could make a tentative diagnosis of myelolipoma (Settakorn et al. 1999, Hasan et al. 2008).

Adrenal myelolipoma is a well-demarcated cortical tumour, which is yellow to red depending on the relative proportion of the fat and hematopoietic components. The mean maximum dimension of the adrenal myelolipoma in the large ranges from 40 to $60 \mathrm{~mm}$ (Lam \& Lo 2001, Zhao et al. 2014). From the pooled data of some large series in the literature, the mean maximum dimension of the tumour was $63 \mathrm{~mm}$ (Table 1). The tumour could be very big. The largest adrenal myelolipoma was reported by Lamont and coworkers in the right adrenal gland of a 50-year-old man, which is $400 \mathrm{~mm}$ in diameter and

Published by Bioscientifica Ltd. 
having a weight of $4254 \mathrm{~g}$ (Lamont et al. 2002). Also, the case reported by Akamatsu and coworkers in the left adrenal gland of a 51-year-old man weighed $6000 \mathrm{~g}$ $(310 \mathrm{~mm})$, which is the heaviest adrenal myelolipoma reported (Akamatsu et al. 2004).

On histological examination, myelolipoma is composed of mature adipocytes and bone marrow (haematopoietic elements) (Fig. 1B). The latter means may consist of different cells of myeloid (white blood cell-forming), erythroid (red blood cell forming) and megakaryocytic (platelet forming) lines. Calcification was noted in 30\% of adrenal myelolipoma (Kenney et al. 1998). Heterotopic bones have been reported in a few adrenal myelolipomas (Mitsui et al. 2014). Differential diagnoses include other less common lipomatous lesions.

Adrenal myelolipoma could occur together with adrenal adenoma as collision tumour in the adrenal gland. This is not surprising as these tumours are common tumours in adrenal gland. In the literature, approximately 20 cases have been documented (Caliumi et al. 2004, Ong et al. 2007, Lu et al. 2008, Yamada et al. 2011). $\mathrm{Lu}$ and coworkers analysed 17 cases reported in the literature and noted that they were often noted in females (male-to-female ratio $=1: 3$ ) and in the left adrenal gland (Lu et al. 2008). The myelolipomas noted in this setting was often small and with diameter ranged from $5 \mathrm{~mm}$ to $30 \mathrm{~mm}$ (Caliumi et al. 2004, Lu et al. 2008). Many of these are non-functional adenomas. There are some other lesions reported that could co-exist with adrenal myelolipoma such as ganglioneuroma, pheochromocytoma, hibernoma, etc. (Schwartz \& Wasson 2003, Shenoy et al. 2015).

The genetic profile of adrenal myelolipoma is rarely mentioned. Chang and coworkers reported an adrenal myelolipoma with a chromosomal translocation $(3 ; 21)$ (q25;p11) (Chang et al. 2002). Similar change is noted in haematopoietic neoplasm reflecting that myelolipoma could derive from misplaced haematopoietic cells. Also, Bishop and coworkers have reported that eight of the 11 myelolipomas from female patients had non-random $\mathrm{X}$-chromosome inactivation. These findings suggest clonal origin of myelolipoma (Bishop et al. 2006).

No malignant progression of adrenal myelolipoma has been reported. In the literature, the longest clinical follow-up reported in the literature was 12 years (Lam \& Lo 2001). Managements of the large/symptomatic tumours are by surgery as large myelolipomas

Table 2 Clinical and pathological features of adrenal lipomas in the literature.

(

\begin{tabular}{|c|c|c|c|c|}
\hline $\begin{array}{l}\text { Author/year/country of } \\
\text { publication }\end{array}$ & Sex/age & Side & $\begin{array}{l}\text { Size/weight } \\
(\mathrm{mm} / \mathrm{g})\end{array}$ & Presentation \\
\hline Lange/1966/Germany & $\mathrm{M} / 54$ & Right & $25 /-$ & Paroxysmal hypertension \\
\hline Prinz/1982/USA & $\mathrm{F} / 73$ & Right & $30 /-$ & Incidental at CT \\
\hline Avinoach/1989/Israel & $\mathrm{F} / 40$ & Right & $13 / 7$ & Incidental at laparotomy \\
\hline \multirow[t]{3}{*}{ Lam/1997 and 2001/Hong Kong } & $\mathrm{F} / 64$ & Right & $80 / 190$ & Incidental at US \\
\hline & $\mathrm{M} / 78$ & Right & $45 / 24$ & Incidental at autopsy \\
\hline & $\mathrm{M} / 65$ & Left & $20 /-$ & Incidental at autopsy \\
\hline Ghavamian/1998/USA & $\mathrm{F} / 50$ & Left & $80 / 80$ & Incidental in tuberculosis \\
\hline Sharma/1998/India & $\mathrm{M} / 45$ & Right & $120 / 225$ & Lumbar pain \\
\hline Büttner/1999/Germany & $\mathrm{M} / 50$ & Right & $11 /-$ & Incidental at autopsy \\
\hline Milathianakis/2002/Greece & $\mathrm{M} / 39$ & Right & $200 / 2900$ & Incidental at US/CT \\
\hline \multirow[t]{2}{*}{ Rodríguez-Calvo/2007/Spain } & $\mathrm{M} / 70$ & Left & $10 /-$ & Incidental at autopsy \\
\hline & $\mathrm{M} / 35$ & Right & $20 / 18$ & Incidental at autopsy \\
\hline Shumaker/2008/USA & $\mathrm{M} / 68$ & Left & $70 / 135$ & Left flank pain \\
\hline Gupta/2009/India & $\mathrm{M} / 51$ & Right & $90 /-$ & Incidental at CT \\
\hline Shah/2009/Pakistan & $\mathrm{M} / 35$ & Right & $50 / 200$ & Abdominal pain/haematuria \\
\hline Singaporewalla/2009/Singapore & $\mathrm{M} / 44$ & Left & $156 /-$ & $\begin{array}{l}\text { Abdominal pain, CT } \\
\text { Retroperitoneal bleeding }\end{array}$ \\
\hline Goldenberg/2011/USA & $\mathrm{M} / 55$ & Right & $70 /-$ & Abdominal pain \\
\hline Gunay/2011/Turkey & $\mathrm{F} / 68$ & Left & 70/- & Incidental at MRI \\
\hline Kapetanakis/2011/Greece & $\mathrm{F} / 54$ & Left & $160 / 950$ & Postprandial pain \\
\hline Patel/2011/India & $\mathrm{M} / 43$ & Right & $150 / 810$ & Incidental at US \\
\hline Jain/2012/India & $\mathrm{F} / 55$ & Right & $120 /-$ & Right flank pain \\
\hline \multirow[t]{3}{*}{ Zhao/2014/China } & $\mathrm{F} / 31$ & Right & $40 / 18$ & Incidental \\
\hline & $\mathrm{F} / 60$ & Right & $100 / 172$ & Incidental \\
\hline & $\mathrm{F} / 51$ & Right & $60 / 112$ & Back pain \\
\hline Total & $10 \mathrm{~F} / 14 \mathrm{M}$ & 17 right/7 left & - & 15 asymptomatic; 9 symptomatic \\
\hline Average & 54 & - & $75 / 417$ & - \\
\hline
\end{tabular}

\begin{tabular}{|c|c|}
\hline Imaging & $\begin{array}{c}\text { Follow-up } \\
\text { (year) }\end{array}$ \\
\hline Not done & - \\
\hline $\mathrm{CT}$ & - \\
\hline Not done & - \\
\hline US & 7 \\
\hline Not done & - \\
\hline Not done & - \\
\hline $\mathrm{CT}$ & - \\
\hline US/CT & 1 \\
\hline Not done & - \\
\hline US/CT & - \\
\hline Not done & - \\
\hline Not done & - \\
\hline CT/MRI & - \\
\hline CT & - \\
\hline US/CT & - \\
\hline \multicolumn{2}{|l|}{-} \\
\hline $\mathrm{CT}$ & - \\
\hline MRI & - \\
\hline $\mathrm{CT}$ & 6 \\
\hline US/CT/MRI & 0.3 \\
\hline US/CT & - \\
\hline NA & 6.2 \\
\hline NA & 4.6 \\
\hline NA & 3.4 \\
\hline- & - \\
\hline- & 4.1 \\
\hline
\end{tabular}

$\mathrm{CT}$, computed tomography; MRI, magnetic resonance imaging; NA, not available; US, ultrasonography. 
(such as measuring more than $60 \mathrm{~mm}$ ) are prone to spontaneous rupture. Most of the centres worldwide do not operate for asymptomatic adrenal myelolipoma less than $40 \mathrm{~mm}$ in diameter (Shenoy et al. 2015).

\section{Adrenal lipoma}

There are 24 well-documented cases of adrenal lipomas in the English literature (Table 2) (Lange 1966, Prinzetal. 1982, Avinoach et al. 1989, Lam et al. 1997, Ghavamian et al. 1998, Sharma et al. 1998, Büttner 1999, Lam \& Lo 2001, Milathianakis et al. 2002, Rodríguez-Calvo et al. 2007, Shumaker et al. 2008, Gupta et al. 2009, Shah \& Bhatti 2009, Singaporewalla et al. 2009, Goldenberg et al. 2011, Gunay et al. 2011, Kapetanakis et al. 2011, Patel et al. 2011, Jain et al. 2012, Zhao et al. 2014). The first case in the English literature was reported by Lange in 1966 (Lange 1966). It appears that many adrenal lipomas were reported in the Asian population as two-third (16 of 24) of the reported cases were noted in the Asian population. The prevalence of the tumour is low, and there is no large series of adrenal lipoma in the literature. In 2001, Lam and Lo reported 3 cases in a 30-year period and adrenal lipoma accounted for $0.7 \%$ of the primary adrenal tumours (Lam \& Lo 2001). In a more recent series, Zhao and coworkers reported 3 cases of adrenal lipoma in a 31-year period. They reported that the tumour accounted for $4 \%$ of all adrenal lipomatous tumours (Zhao et al. 2014).

In contrast to other adrenal lipomatous lesions, adrenal lipoma is more common in males. The femaleto-male ratio is 0.7 to 1 (10 males and 14 females). Also, adrenal lipoma was found in patients in the sixth decade of life (mean age $=54$; age range $=35-78$ ). One-third of the reported cases were in this age group.

All the adrenal lipomas noted in the literature are nonfunctional. It is not surprising that majority of the cases were incidental findings either at autopsy or at radiological examination. There were 9 symptomatic cases as a result of the mechanic effect of the tumours. The case reported by Lange in 1966 showed paroxysmal hypertension, which is assumed to be due to mechanical irritation of the adrenal medulla to produce catecholamines. The symptomatic patients with adrenal lipoma presented with pain (Lange 1966).

Adrenal lipoma is more frequently noted on in the right adrenal gland (17 on the right; 7 on the left; rightto-left ratio=2.4-1). In the literature, Milathianakis and coworkers reported a giant adrenal lipoma of $200 \mathrm{~mm}$ in dimension and 2900g (Milathianakis et al. 2002). The mean maximum dimension of adrenal lipomas was
$75 \mathrm{~mm}$ (range, $10-200 \mathrm{~mm}$ ). Slightly over half (54\%; $13 / 24$ ) of the tumours noted in the literature were larger than $60 \mathrm{~mm}$. Also, the mean weight of the adrenal gland with the tumour was $417 \mathrm{~g}$ (range, 7-2900 g). Apart from the giant adrenal lipoma reported by Milathianakis and coworkers, the other adrenal lipomas were less than $1000 \mathrm{~g}$ (Milathianakis et al. 2002).

Apart from detected at autopsy, the adrenal lipomas were often detected as incidentalomas on radiological examination. Ultrasonography of the abdomen showed a hyperechoic mass in the region of adrenal gland (Lam et al. 1997, Sharma et al. 1998, Milathianakis et al. 2002, Patel et al. 2011). Recently, Puri and coworkers have reported the use of endoscopic ultrasound-guided fine aspiration on a patient with adrenal lipoma (Puri et al. 2015). However, no detail information was reported in

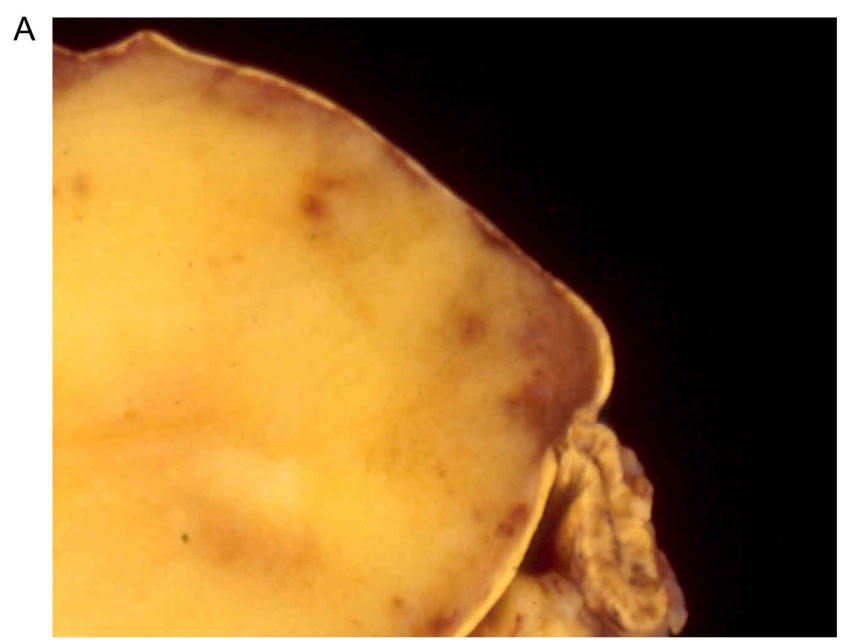

B

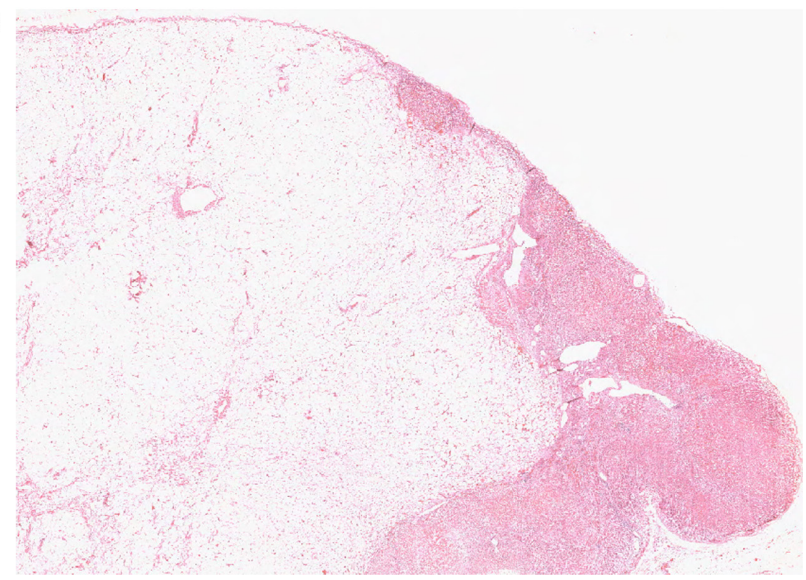

Figure 2

Adrenal lipoma. (A) Adrenal lipoma composed of yellow homogenous fatty tissue encased by adrenal cortex. Note the adrenal gland at one end of the tumour. (B) Microscopic appearance of the adrenal lipoma showing that it is composed of mature adipose tissue with no bone marrow elements (haematoxylin and eosin $\times 1$ ).

Published by Bioscientifica Ltd 
the case. Most often, adrenal lipoma was detected by computed tomography scan, which demonstrated a well-circumscribed, non-enhancing supra-renal mass of adipose tissue density. Magnetic resonance imaging was not often preformed and showed similar findings to those in computed tomography scan (Shumaker et al. 2008, Patel et al. 2011). Nevertheless, the diagnosis of adrenal lipoma could only be made on histological examination.

On macroscopic examination, the tumour is well demarcated and composed of yellow adipose tissue
(Fig. 2A). Most of the tumours are yellow with homogenous and soft cut sections. However, patches of haemorrhages could be seen (Lam et al. 1997, Singaporewalla et al. 2009, Kapetanakis et al. 2011, Jain et al. 2012). In one case, the bleeding from the vessels in the lipoma resulted in retroperitoneal bleeding (Singaporewalla et al. 2009).

On microscopic examination, adrenal lipoma is composed of mature adipose tissue (Fig. 2B). Calcification was noted in 3 of the reported cases (Ghavamian et al. 1998, Lam \& Lo 2001, Milathianakis et al. 2002).

Table 3 Clinical and pathological features of adrenal teratoma in the literature.

\begin{tabular}{|c|c|c|c|c|c|c|c|}
\hline $\begin{array}{l}\text { Author/year of publication/ } \\
\text { country of publication }\end{array}$ & $\begin{array}{l}\text { Sex/age } \\
\text { (years) }\end{array}$ & Side & $\begin{array}{l}\text { Size/weight } \\
(\mathrm{mm} / \mathrm{g})\end{array}$ & Presentation & Imaging & Follow-up & Remarks \\
\hline \multirow[t]{2}{*}{ Lam/1999/Hong Kong } & $\begin{array}{l}\mathrm{F} / 18 \\
\mathrm{M} / 17\end{array}$ & $\begin{array}{l}\text { Left } \\
\text { Right }\end{array}$ & $\begin{array}{l}110 / 67 \\
75 / 74\end{array}$ & $\begin{array}{l}\text { Back pain } \\
\text { Back pain }\end{array}$ & $\begin{array}{l}\mathrm{CT} \\
\mathrm{CT} / \mathrm{MRI}\end{array}$ & $\begin{array}{l}7 \text { years } \\
1 \text { year }\end{array}$ & \\
\hline & $\mathrm{F} / 37$ & Left & $100 /-$ & Back pain & $\mathrm{CT}$ & 8 year & \\
\hline Kaneko/1998/Japan & $\mathrm{M} / 46$ & Right & $90 /-$ & Abdominal mass & US/CT/MRI & - & $\begin{array}{l}\text { Labelled as } \\
\text { dermoid cyst }\end{array}$ \\
\hline Khong/2002/Hong Kong & $\mathrm{F} / 8$ & Right & $60 /-$ & Asymptomatic & US/CT & - & \\
\hline Bedri/2002/USA & $F / 57$ & Left & $80 / 200$ & Abdominal pain & CT/MRI & - & \\
\hline Polo/2004/Spain & $\mathrm{F} / 21$ & Left & $380 / 10,000$ & Abdominal pain & $\mathrm{CT}$ & - & \\
\hline Hui/2004/Hong Kong & $\mathrm{M} / 77$ & Left & $170 /-$ & Asymptomatic & $\mathrm{XR/US/CT}$ & - & \\
\hline \multirow[t]{2}{*}{ Castillo/2006/Chile } & $\mathrm{M} / 8$ & Right & $80 /-$ & Abdominal pain & $\mathrm{CT}$ & 3 year & \\
\hline & $\mathrm{F} / 61$ & Left & $80 / 54$ & Asymptomatic & $\mathrm{CT}$ & - & \\
\hline James/2009/USA & $\mathrm{M} /$ new born & Right & $140 /-$ & Respiratory distress & US/CT/MRI & - & \\
\hline Oguzkurt/2009/Turkey & M/45 days & Left & $55 /-$ & Mass in antenatal US & US/MRI & 1 year & $\begin{array}{l}\text { Increased } \\
\text { serum AFP }\end{array}$ \\
\hline Shrestha/2010/Nepal & $\mathrm{F} / 40$ & Right & $90 /-$ & Asymptomatic & US/CT & & \\
\hline Ersoz/2011/Turkey & $\mathrm{M} / 8$ & Right & $100 /-$ & Abdominal pain & US/CT & 6 months & $\begin{array}{l}\text { With } \\
\text { neurocytoma }\end{array}$ \\
\hline Kim/2011/South Korea & $F / 38$ & Left & $38 / 267$ & Asymptomatic & US/CT & - & \\
\hline $\mathrm{Li} / 2011 /$ China & $\mathrm{F} / 4$ & Left & $30 /-$ & Asymptomatic & CT/MRI & 13 months & \\
\hline Ciftci/2013/Turkey & $\mathrm{M} / 3$ months & Left & $83 /-$ & Abdominal distension & US/CT & - & \\
\hline Bhatti/2013/Saudi Arabia & $\mathrm{M} / 22$ & Left & $100 / 484$ & Left flank pain & $\mathrm{CT}$ & 6 months & \\
\hline Tang/2014/China & $\mathrm{F} / 39$ & Right & $225 / 1620$ & Hypertension & $\mathrm{CT}$ & - & \\
\hline \multirow[t]{2}{*}{ Zhao/2014/Hong Kong } & $\mathrm{F} / 21$ & Right & $60 / 48.5$ & Back pain & US/CT & 6.7 years & \\
\hline & $F / 35$ & Right & $80 / 135.5$ & Asymptomatic & US/CT & 4.8 years & \\
\hline Mardi/2015/India & $F / 24$ & Left & $190 /-$ & Abdominal pain & $\mathrm{CT}$ & 1.5 years & $\begin{array}{l}\text { Complete } \\
\text { colon wall } \\
\text { seen }\end{array}$ \\
\hline Li/2015a/China & $\mathrm{M} / 49$ & Right & $110 /-$ & Abdominal mass & US/CT & 8 months & \\
\hline \multirow[t]{5}{*}{ Li/2015b/China } & $F / 21$ & Right & $85 /-$ & Asymptomatic & US/CT & - & \\
\hline & $\mathrm{F} / 16$ & Right & $90 /-$ & Asymptomatic & US/CT & - & \\
\hline & $\mathrm{F} / 43$ & Left & $49 /-$ & Asymptomatic & US/CT & - & \\
\hline & $\mathrm{F} / 49$ & left & $53 /-$ & Asymptomatic & US/CT & - & \\
\hline & $\mathrm{F} / 51$ & Right & $24 /-$ & Asymptomatic & US/CT & - & \\
\hline Nadeem/2015/Pakistan & $\mathrm{M} / 19$ & Right & $80 /-$ & Lumbar pain & $\mathrm{CT}$ & & 1 year \\
\hline Ratkal/2015/India & $F / 29$ & Right & $100 / 130$ & Abdominal pain & US/CT & - & \\
\hline Bhatia/2016/India & $F / 24$ & Left & $24 /-$ & $\begin{array}{l}\text { Abdominal pain/cough } \\
\text { US/CT }\end{array}$ & - & $\begin{array}{l}\text { Rupture } \\
\text { and } \\
\text { involves } \\
\text { lung }\end{array}$ & \\
\hline Narla/2016/India & $F / 2$ & Right & $60 /-$ & Abdominal pain & MRI & - & With carcinoid \\
\hline Total & 21F:11M & $17 \mathrm{R} / 15 \mathrm{~L}$ & - & $\begin{array}{l}20 \text { symptomatic/12 } \\
\text { asymptomatic }\end{array}$ & - & - & \\
\hline Average & 27 years & - & $99 / 1189$ & - & - & 2.8 years & \\
\hline
\end{tabular}

CT, computed tomography; F, female; g, gram; L, left; M, male; MRI, magnetic resonance imaging; R, right; US, ultrasonography; XR, abdominal X-ray; -, not available. 
Chronic inflammatory cells (Kapetanakis et al. 2011) were found in a case having symptoms for 10 years. Also, a case had active inflammation and abscess as a result of adjacent infection as a result of percutaneous nephrolithotomy (Gupta et al. 2009). In addition, a case had necrosis, which is related to co-existing tuberculosis (Ghavamian et al. 1998).

The main differential diagnosis of adrenal lipoma is myelolipoma, which is much more common in incidence. The only feature that differentiates lipoma from myelolipoma is the absence of myeloid elements in the adrenal lipoma. Thus, adequate tissue blocks should be sampled from non-fatty areas such as haemorrhagic region or calcified areas to rule out the presence of myeloid elements.

Of the 24 adrenal lipomas in the literature, 6 were detected at autopsy and 18 were detected at examination of surgical resected specimens. In the latter group, 5 were operated by laparoscopic approach and 13 by open surgery. Adrenal lipoma is a benign tumour.
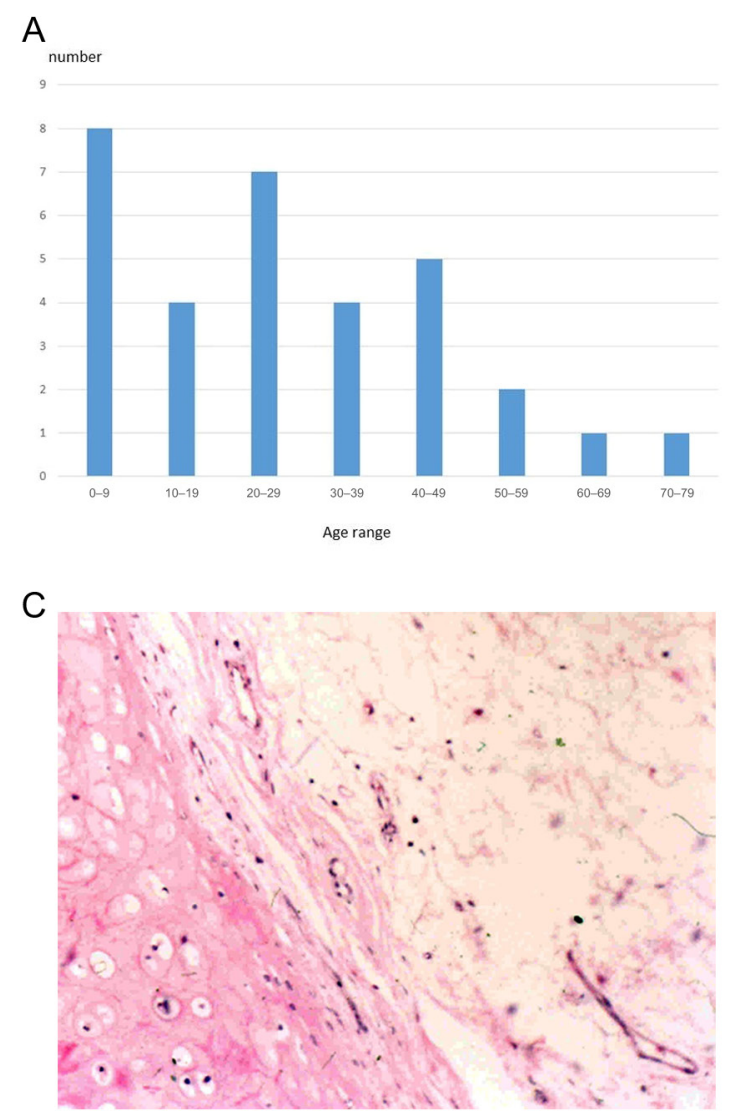

In the literature, clinical follow-up was identified in $39 \%$ (7 of the 18) of the patients underwent surgery. The longest clinical follow-up of the lesion documented was 7 years (Lam \& Lo 2001). None of the tumours had local recurrence or signs of malignancy on clinical follow-up.

In summary, adrenal lipoma is rare. The diagnosis could only be possible on surgical removed specimen. It is a benign lesion. However, it could be symptomatic and presented with pain as a result of complications.

\section{Adrenal teratoma}

In the English literature, 32 adrenal teratomas with welldocumented features were reported (Table 3) (Lam \& Lo 1999, Kaneko et al. 2000, Bedri et al. 2002, Khong et al. 2002, Hui et al. 2004, Polo et al. 2004, Castillo et al. 2006, James et al. 2009, Oguzkurt et al. 2009, Shrestha \& Lalchan 2010, Ersoz et al. 2011, Kim et al. 2011, Li et al. 2011, Bhatti et al. 2013, Ciftci et al. 2013, Tang et al. 2014, Zhao et al. 2014, Li et al. 2015a,b, Mardi et al. 2015,

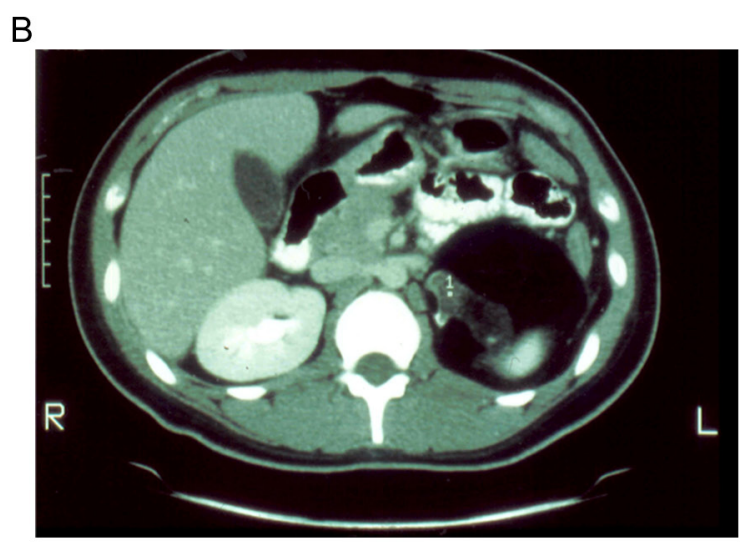

D

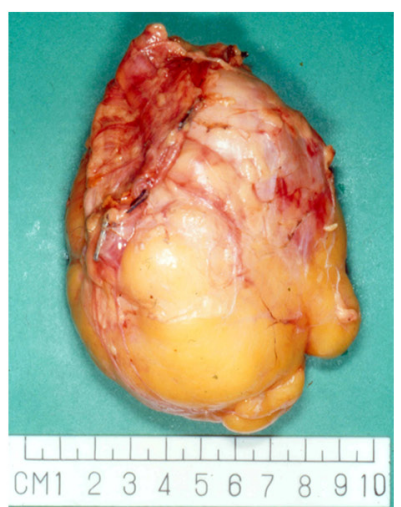

Figure 3

Adrenal teratoma. (A) The age distribution of adrenal mature teratoma showing the tumour is more common in the age groups (0-9) as well (20-29). (B) CT scan showing a well-demarcated heterogeneous mass in the left adrenal region. (C) Macroscopic appearance showing the tumour is composed of large amount of fatty tissue. (D) Microscopic appearance showing the presence of cartilage as well as adipose tissue (haematoxylin and eosin $\times 20$ ). 
Nadeem et al. 2015, Ratkal et al. 2015, Bhatia et al. 2016, Narla et al. 2016). Adrenal teratoma was first reported by Lam and Lo in 1999 (Lam \& Lo 1999). In a 30-year study period, the authors have reported 3 adrenal teratomas. The adrenal teratomas accounted for $1.3 \%$ of the surgical resected primary adrenal tumours and $0.7 \%$ of all primary adrenal tumours (Lam \& Lo 2001). In 2014, Zhou and coworkers in their 31-year study showed 2 adrenal teratomas, which comprised $2.7 \%$ of adrenal lipomatous tumours (Zhao et al. 2014). The other large series was by $\mathrm{Li}$ and coworkers who reported 5 adrenal teratomas and the prevalence of the lesion in adrenal diseases in a 5-year period is $0.13 \%$ (Li et al. $2015 b$ ).

The majority of the adrenal teratomas were reported in Asian populations. Other than these, a few cases were reported in United States of America (USA) $(n=3)$, Chile $(n=2)$ and Spain $(n=1)$. In the cases noted in Asian populations, half of the reported cases $(48 \% ; 15 / 31)$ were reported from Chinese patients from Hong Kong or China. The other patients were from India $(n=4)$, Nepal $(n=1)$, Pakistan $(n=1)$, South Korea $(n=1)$ and Japan $(n=1)$. Also, there are three cases reported from Turkey and one case from Saudi Arabia.

Adrenal teratoma was more common in females with female-to-male ratio=1.9-1 ( 21 females; 11 males). From the pooled data in literature, adrenal teratoma occurs in a wide age range with the median age at presentation at 23 years. There is bimodal age distribution for the cases (Fig. 3A). The tumours are common in the first decade as well as the third decade of life. There is no gender difference in the age distribution.

Slightly over $60 \%$ (20 of 32; 62.5\%) of the patients with adrenal teratoma were symptomatic. The most common symptom is abdominal pain $(n=14)$. Other clinical presentations noted include abdominal distension and hypertension. A case was noted in a new born boy in respiratory distress (James et al. 2009). Bhatia and coworkers reported an adrenal teratoma complicated by extension through diaphragm and involving the lung giving the symptom of coughing (Bhatia et al. 2016). All the cases are non-functional on biochemical investigations. Oguzkurt and coworkers have reported an adrenal teratoma with increase serum alpha fetoprotein level in a 45-day-old infant (Oguzkurt et al. 2009). However, no immature element was noted on histology.

CT or MRI had been performed in all the patients with adrenal teratomas reported in the literature. The examination showed mainly a fatty mass as in other adrenal lipomatous tumours. However, when compared to other adrenal lipomatous tumours, adrenal teratomas were often cystic, heterogeneous and commonly having calcification (Fig. 3B). From the pooled data in literature with detailed descriptions, 90\% (26 of 29) of adrenal teratomas were cystic and $76 \%$ (22 of 29) showed calcification. The typical radiological features of adrenal teratoma are heterogeneous mass in the adrenal region containing fluid, adipose tissue and/or serum in the form of a fat-fluid level and with calcification. Pre-operative diagnosis of adrenal teratoma was made in four (13\%) adrenal teratomas (Li et al. 2015a, Mardi et al. 2015, Nadeem et al, 2015).

Adrenal teratoma has no side preponderance (right=17; left=15). From the pooled data in the literature, the mean maximum dimension of the tumour is $99 \mathrm{~mm}$ (range, $24-380 \mathrm{~mm}$ ). Eighty-four percent (27 of 32) of the reported cases were of diameter $60 \mathrm{~mm}$ or above. A giant adrenal teratoma was reported by Polo and coworkers, which weighed $10 \mathrm{~kg}$ (Polo et al. 2004). The other tumours weighed between $48.5 \mathrm{~g}$ and $1620 \mathrm{~g}$. On cut sections, adrenal teratoma was often cystic. Greasy sebaceous material, skin and hair are commonly noted. In addition, it may be composed of large mass of adipose tissue mimicking other fatty tumours such as myelolipoma and lipoma (Lam \& Lo 1999) (Fig. 3C). In some instances, cartilage, bone and teeth as well as mucinous substance could be noted on macroscopic examination (Shrestha \& Lalchan 2010, Nadeem et al. 2015).

On histological examination, all cases were mature teratoma. Characteristically, they are mostly cystic and contain tissues from 3 germ layers (Fig. 3D). Mardi and coworkers noted a case with complete layers of colon wall (Mardi et al. 2015). No evidence of immature elements or malignancy noted. Erosoz described a case in an 8-year-old boy with co-existing neurocytoma (Ersoz et al. 2011). Also, Narla and coworkers noted an adrenal teratoma associated with carcinoid in a 2-year-old girl (Narla et al. 2016).

Teratomas are result of abnormal development of pluripotent cells: embryonic cells or germ cells. Teratomas of embryonic origin are congenital. For instance, 3 adrenal teratomas occurred in young infants; one antenatal, one at birth and one at 3 months of age (James et al. 2009, Oguzkurt et al. 2009, Ciftci et al. 2013). Teratomas of germ cell origin could be congenital or in adult. The close anatomic association of adrenal cortex with the urogenital apparatus and its embryological development from coelomic epithelium make it a possible site of development of teratoma. 
Table 4 Clinical and pathological features of adrenal angiomyolipoma in the literature.

\begin{tabular}{|c|c|c|c|c|c|c|c|c|}
\hline $\begin{array}{l}\text { Author/year/country of } \\
\text { publication }\end{array}$ & Sex/age & Side & $\begin{array}{l}\text { Size/weight } \\
(\mathrm{mm} / \mathrm{g})\end{array}$ & Presentation & Syn. & Imaging & $\begin{array}{c}\mathbf{F U} \\
\text { (year) }\end{array}$ & Remarks \\
\hline \multirow[t]{2}{*}{$\mathrm{Lam} / 2001 / \mathrm{HK}$} & $\mathrm{F} / 46$ & Left & $80 / 115$ & Incidental at CT & - & CT & 1 & - \\
\hline & $\mathrm{M} / 20$ & Left & $2 / 3$ & $\begin{array}{l}\text { Incidental at } \\
\text { nephrectomy }\end{array}$ & TS & - & 8 & $\begin{array}{l}\text { AML in kidney } \\
\text { and liver }\end{array}$ \\
\hline Elsayes/2005/USA & $F / 49$ & Right & $122 /-$ & Incidental at CT & TS & CT/MRI & - & $\begin{array}{l}\text { AML in left } \\
\text { kidney }\end{array}$ \\
\hline Godara/2007/India & $\mathrm{F} / 45$ & Left & $150 /-$ & Epigastric discomfort & - & CT & 1.5 & - \\
\hline Sutter/2007/Switzerland & $\mathrm{F} / 32$ & Right & 90/- & Abdominal pain & LAM & $\mathrm{CT}$ & - & - \\
\hline D'Antonio/2009/Italy & $\mathrm{M} / 42$ & Left & $60 / 100$ & $\begin{array}{l}\text { Back pain, anaemia, } \\
\text { fever }\end{array}$ & - & CT/MRI & 1 & Epitheloid type \\
\hline Chee Kong/2010/Malaysia & $M / 61$ & Left & $100 /-$ & Left loin pain & - & $\mathrm{CT}$ & 1 & - \\
\hline Yener/2011/Turkey & $\mathrm{F} / 45$ & Right & $50 /-$ & Epigastric discomfort & - & US/CT & 0.25 & - \\
\hline $\mathrm{Hu} / 2012 /$ China & $\mathrm{F} / 55$ & Right & $160 /-$ & Abdominal pain & - & $\mathrm{CT}$ & 0.50 & - \\
\hline Hafeez Bhatti/2012/Pakistan & $\mathrm{F} / 72$ & Right & $90 /-$ & Abdominal pain & - & $\mathrm{CT}$ & - & - \\
\hline Sazuka/2013/Japan & $F / 68$ & Right & $66 /-$ & Back pain & - & CT/MRI/PET & - & - \\
\hline Goswami/2014/India & $F / 43$ & Right & $95 /-$ & Right flank pain & - & $\mathrm{CT}$ & - & - \\
\hline \multirow[t]{2}{*}{ Zhao/2014/China } & $\mathrm{F} / 47$ & Left & $60 / 45$ & Asymptomatic & - & $\mathrm{CT} / \mathrm{MRI}$ & 6.20 & - \\
\hline & $\mathrm{M} / 70$ & Left & $80 / 121$ & Asymptomatic & - & CT/MRI & 5.40 & - \\
\hline Li/2015/China & $M / 53$ & Left & $90 /-$ & Abdominal pain & - & CT/PET & 8 & - \\
\hline Kwazneski li/2016/USA & F/65 & Right & $65 / 626$ & Abdominal pain & - & US/CT & 3 & - \\
\hline Total & $11 \mathrm{~F} / 5 \mathrm{M}$ & $\begin{array}{c}8 \text { right/ } \\
8 \text { left }\end{array}$ & - & $\begin{array}{l}11 \text { symptomatic/5 } \\
\text { asymptomatic }\end{array}$ & - & - & - & - \\
\hline Average & 51 & - & $88 / 168$ & - & - & - & 3.30 & - \\
\hline
\end{tabular}

AML, angiomyolipoma; CT, computed tomography; F, female; FU, follow-up; LAM, lymphangioleiomyomatosis; M, male; MRI, magnetic resonance imaging; PET, positron emission tomography; Syn., syndrome associated; TS, tuberous sclerosis; US, ultrasonography; -, not available.

The main differential diagnosis of adrenal teratoma was to differentiate it from retroperitoneal teratoma. It is often difficult and many of the cases reported in the literature actually mentioned clearly that it is not possible to differentiate the teratoma arising in these two sites. The finding of normal adrenal cortex encasing the tumour could be the most important sign of adrenal teratoma. The other possible differential diagnosis is metastatic malignant teratoma. A case of malignant teratoma presented with adrenal mass has been reported (McMillan \& Horwich 1987).

In the literature, 19 of the 32 cases had follow-up information. The clinical follow-up of patients with adrenal teratoma ranged from half a year to 8 years (mean $=2.7$ years). None of the patients had recurrent or malignant change.

\section{Adrenal angiomyolipoma}

Angiomyolipoma is a member of the family of neoplasms that derive from perivascular epitheloid cells (PEC) (PEComa family) (Thway \& Fisher 2015). It could occur in the settings of tuberous sclerosis complex. Lymphangioleiomyomatosis (LAM) is as an infrequent symptomatic pulmonary complication in tuberous sclerosis (Hancock et al. 2002). It also belongs to the
PEComa family. Angiomyolipoma is a tumour composed of blood vessels, smooth muscle (myo) cells and fat cells. The tumour is positive for melanocytic (HMB-45 and melan-A) and smooth muscle marker (smooth muscle actin). It most often occurs in the kidney or liver.

Adrenal angiomyolipoma is very rare. Because of the anatomical location, it is difficult to distinguish between primary renal and primary adrenal angiomyolipoma on radiological examination. A total

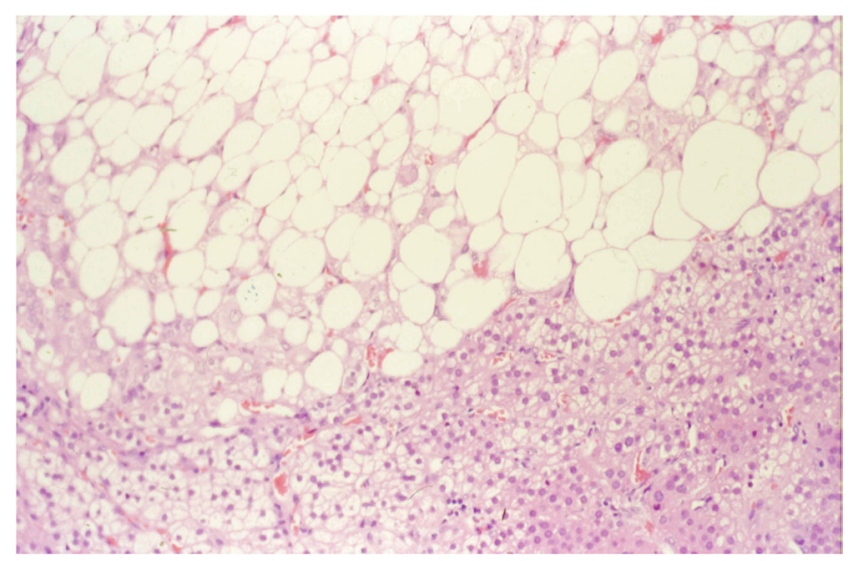

Figure 4

Adrenal angiomyolipoma. Microscopic appearance of the adrenal angiomyolipoma showing the presence of blood vessels and myxoid cells in additional to the adipose tissue (haematoxylin and eosin $\times 20$ ).

Published by Bioscientifica Ltd. 
of 16 well-documented cases have been noted in the literature (Table 4) (Lam \& Lo 2001, Elsayes et al. 2005, Godara et al. 2007, Sutter et al. 2007, D'Antonio et al. 2009, Chee Kong et al. 2010, Yener et al. 2011, Hu \& Xi 2012, Hafeez Bhatti et al. 2013, Sazuka et al. 2013, Goswami et al. 2014, Zhao et al. 2014, Li et al. 2015a,b, Kwazneski et al. 2016). Most of the cases (12 of 16; 75\%) were reported in Asia.
Lam and Lo first documented the histology of 2 adrenal angiomyolipoma in the literature in 2001 (Lam $\&$ Lo 2001). Both cases were asymptomatic. In the report, angiomyolipoma accounted for $0.5 \%$ and $0.8 \%$ of the primary and surgical resected primary adrenal tumours, respectively. On the other hand, most of the reported cases in the literature were symptomatic $(69 \% ; n=11)$ and presented with abdominal pain.

Table 5 Clinical and pathological features of other adrenal tumours with component of adipose tissue in the literature.

\begin{tabular}{|c|c|c|c|c|c|c|c|c|}
\hline Author/year/country & Diagnosis & Sex/age & Side & $\begin{array}{l}\text { Size/weight } \\
(\mathrm{mm} / \mathrm{g})\end{array}$ & Presentation & Imaging & FU (years) & Remarks \\
\hline $\begin{array}{l}\text { Lam/2001/Hong } \\
\text { Kong }\end{array}$ & Liposarcoma & $F / 36$ & Right & $180 / 783$ & $\begin{array}{l}\text { Right loin } \\
\text { pain }\end{array}$ & CT/MRI & 2 & $\begin{array}{l}\text { Detected at } \\
\text { pregnancy, cystic }\end{array}$ \\
\hline Zhao/2014/China & Liposarcoma & $F / 31$ & Right & $123 / 1250$ & $\begin{array}{l}\text { Right back } \\
\text { pain }\end{array}$ & CT/MRI & 7.4 & - \\
\hline Schwartz/2003/USA & Hibernoma & $\mathrm{F} / 42$ & Right & $11 /-$ & Incidental & $\mathrm{CT}$ & - & Had myelolipoma \\
\hline $\begin{array}{l}\text { Fernando Val- } \\
\text { Bernal/2013/Spain }\end{array}$ & Hibernoma & $\mathrm{F} / 55$ & Left & $17 / 75$ & Incidental & $\mathrm{CT}$ & - & Had adenoma \\
\hline Sato/1995/Japan & $\begin{array}{l}\text { Adenoma } \\
\text { with fat }\end{array}$ & $\mathrm{M} / 47$ & Left & $40 /-$ & $\begin{array}{l}\text { Abdominal } \\
\text { pain }\end{array}$ & CT/MRI & - & \\
\hline \multirow[t]{2}{*}{ Papotti/1996/Italy } & $\begin{array}{l}\text { Adenoma } \\
\text { with fat }\end{array}$ & $\mathrm{F} / 46$ & Right & $100 / 270$ & $\begin{array}{l}\text { Abdominal } \\
\text { pain }\end{array}$ & $\mathrm{CT}$ & $13 / 4$ & $\begin{array}{l}\text { Pre-clinical } \\
\text { Cushing }\end{array}$ \\
\hline & $\begin{array}{l}\text { Adenoma } \\
\text { with fat }\end{array}$ & $\mathrm{F} / 74$ & Left & $65 / 50$ & $\begin{array}{l}\text { Abdominal } \\
\text { pain }\end{array}$ & US/US & 0.5 & $\begin{array}{l}\text { Pre-clinical } \\
\text { Cushing, HCC }\end{array}$ \\
\hline Feldberg/1996/Israel & $\begin{array}{l}\text { Adenoma } \\
\text { with fat }\end{array}$ & $\mathrm{F} / 40$ & Left & $80 /-$ & Lumbar pain & CT/US/MRI & 2 & \\
\hline Uriev/2014/Israel & $\begin{array}{l}\text { Adenoma } \\
\text { with fat }\end{array}$ & $\mathrm{F} / 51$ & Left & $40 / 18$ & Cushing & $\mathrm{CT}$ & - & \\
\hline Mylarapp/2014/India & $\begin{array}{l}\text { Adenoma } \\
\text { with fat }\end{array}$ & $\mathrm{F} / 12$ & Right & $100 /-$ & Hirsutism & CT/US & - & \\
\hline Luo/2015/China & $\begin{array}{l}\text { Adenoma } \\
\text { with fat }\end{array}$ & $\mathrm{M} / 46$ & Right & $20 / 8$ & $\begin{array}{l}\text { Abdominal } \\
\text { pain }\end{array}$ & $\mathrm{CT}$ & - & $\begin{array}{l}\text { Non-functional } \\
\text { adenoma }\end{array}$ \\
\hline Montone/2009/USA & $\begin{array}{l}\text { Cortical } \\
\text { neoplasm } \\
\text { UMP with fat }\end{array}$ & $\mathrm{F} / 50$ & Left & $55 / 105$ & Incidental & $\mathrm{CT}$ & - & $\begin{array}{l}\text { Myelolipomatous } \\
\text { metaplasia }\end{array}$ \\
\hline $\begin{array}{l}\text { Cortical neoplasm } \\
\text { UMP with fat }\end{array}$ & $\mathrm{F} / 56$ & Right & $110 / 249$ & $\begin{array}{l}\text { Abdominal } \\
\text { pain }\end{array}$ & MRI & - & $\begin{array}{c}\text { Myelolipo- } \\
\text { matous } \\
\text { metaplasia }\end{array}$ & \\
\hline \multirow[t]{3}{*}{ Lin/1998/USA } & $\begin{array}{l}\text { Oncocytoma } \\
\text { with fat }\end{array}$ & $\mathrm{F} / 68$ & Left & $80 /-$ & $\begin{array}{l}\text { Abdominal } \\
\text { pain }\end{array}$ & - & $51 / 3$ & \\
\hline & $\begin{array}{l}\text { Oncocytoma } \\
\text { with fat }\end{array}$ & $\mathrm{F} / 41$ & Left & $75 / 85$ & Incidental & - & 8.25 & \\
\hline & $\begin{array}{l}\text { Oncocytoma } \\
\text { with fat }\end{array}$ & $M / 52$ & Right & $90 / 294$ & $\begin{array}{l}\text { Abdominal } \\
\text { pain }\end{array}$ & - & 8 & \\
\hline $\begin{array}{l}\text { Rosenkrantz/2010/ } \\
\text { USA }\end{array}$ & $\begin{array}{l}\text { Oncocytoma } \\
\text { with fat }\end{array}$ & $\mathrm{M} / 52$ & Left & $85 / 182$ & Incidental & CT/MRI & 3 & \\
\hline Izumi/2003/Japan & $\begin{array}{l}\text { ACC with fat } \\
\text { (myxoid) }\end{array}$ & $M / 38$ & Left & $135 / 380$ & Hypertension & $\mathrm{CT} / \mathrm{MRI}$ & - & $\begin{array}{l}\text { Increased cortical } \\
\text { hormones }\end{array}$ \\
\hline Heye/2005/Belgium & ACC with fat & $M / 38$ & Left & 70/145 & Hypertension & US/MRI & - & \\
\hline Egbert/2010/USA & ACC with fat & $M / 41$ & Left & $220 /-$ & $\begin{array}{l}\text { Abdominal } \\
\text { pain }\end{array}$ & CT/MRI & - & \\
\hline $\begin{array}{l}\text { Termote/2007/ } \\
\text { Belgium }\end{array}$ & $\begin{array}{l}\text { Cavernous } \\
\text { hemangioma } \\
\text { with fat }\end{array}$ & $\mathrm{M} / 73$ & Left & $80 / 182$ & Incidental & CT/MRI & - & $\begin{array}{l}\text { Calcification } \\
\text { present }\end{array}$ \\
\hline $\begin{array}{l}\text { Ramsay/1987/ } \\
\text { Canada }\end{array}$ & $\begin{array}{l}\text { Pheochromocy- } \\
\text { toma with lipid }\end{array}$ & $M / 27$ & Right & $30 /-$ & Headaches & $\mathrm{CT}$ & - & $\begin{array}{l}\text { Bilateral pheo- } \\
\text { chromocytoma }\end{array}$ \\
\hline
\end{tabular}

ACC, adrenocortical carcinoma; CT, computed tomography; HCC, hepatocellular carcinoma; MRI, magnetic resonance imaging; NA, not available; UMP, uncertain malignant potential; US, ultrasonography.

http://erc.endocrinology-journals.org DOI: 10.1530/ERC-16-0564
(C) 2017 Society for Endocrinology Printed in Great Britain
Published by Bioscientifica Ltd 
By analysing the features of well-documented cases in the English literature, adrenal angiomyolipoma was more common in females (11 females, 5 males; female-to-male ratio $=2.2: 1$ ). The tumours were noted in a wide age range from 20 to 72 . The mean age at presentation was 51 years with $43 \%(n=7)$ of the cases first noted in the fifth decades of life. It has no site predilection ( 8 on the right side and 8 on the left side)

In a study of 209 patients with renal angiomyolipomas, 11\% $(n=24)$ had tuberous sclerosis (likely or definite) (Lane et al. 2008). Similarly, of the 16 adrenal angiomyolipomas noted in the literature, 2 had tuberous sclerosis and 1 had lymphangioleiomyomatosis; giving a 19\% prevalence of syndrome complex in adrenal angiomyolipomas. There is an additional case of adrenal angiomyolipoma noted in a series of extrathoracic lymphangioleiomyomatosis (Maziak et al. 1996). However, no detail information was given about the case and thus this case was not counted in the current analysis.

Radiologically, the tumour appeared heterogeneous with fat and haemorrhagic component mimicking myelolipoma (Sazuka et al. 2013). It can also be misdiagnosed as adrenocortical tumour (Godara et al. 2007, Yener et al. 2011, Hu \& Xi 2012).

On pathological examination, the dimension of the tumours ranges from $2 \mathrm{~mm}$ to $160 \mathrm{~mm}$ (mean $=88 \mathrm{~mm}$ ) and the weight of the tumours range from 3 to $626 \mathrm{~g}$ (mean $=168 \mathrm{~g}$ ). The histological features of most of the tumours noted in the literature are classical with mixture of the 3 components: vessels, muscles and adipose tissue (Fig. 4). Calcification was documented in 2 cases (Hafeez Bhatti et al. 2013, Kwazneski et al. 2016). Also, one of the cases has epithelioid morphology (D'Antonio et al. 2009).
All the cases reported to date are benign on morphological examination. Over a short mean follow-up period of 3.3 years, all the cases showed no tumour recurrence or metastases.

\section{Other adrenal lipomatous tumours}

The other lipomatous tumours in the adrenal gland are rare. They could be divided into 3 groups; rare primary adrenal lipomatous tumours, adrenocortical tumours with fat component and adrenal tumours with fat component (Table 5).

\section{Rare primary lipomatous tumours}

The rare primary adrenal lipomatous tumours are liposarcoma and hibernoma.

Liposarcoma is the most common retroperitoneal sarcoma. There are four major liposarcoma subtypes: atypical lipomatous tumour/well-differentiated liposarcoma, dedifferentiated liposarcoma, myxoid/ round cell liposarcoma and pleomorphic liposarcoma (Matthyssens et al. 2015). It is very difficult to differentiate whether the liposarcoma is primary in the adrenal or in the soft tissue in the peritoneum. In the literature, two adrenal liposarcomas have been reported (Lam \& Lo 2001, Zhao et al. 2014). They were noted in female patients in the fourth decade of life. Also, both adrenal liposarcomas were myxoid (round cell) liposarcoma. It is worth noting that retroperitoneal liposarcoma are most often of welldifferentiated subtype or dedifferentiated liposarcoma (Matthyssens et al. 2015).

Hibernoma is a tumour composed of brown fat. Histologically, the tumour is composed of primitive embryonal fat characterized by multi-vacuolated

Table 6 Comparison of the major type of fatty tumours in the adrenal gland.

\begin{tabular}{|c|c|c|c|c|}
\hline Parameters & Myelolipoma & Lipoma & Teratoma & Angiomyolipoma \\
\hline $\begin{array}{l}\text { Proportion of surgically } \\
\text { resected adrenal tumour (\%) }\end{array}$ & 3 & 0.4 & 1.3 & 0.8 \\
\hline No of cases reported & $\begin{array}{l}>1200 \text { 2nd common } \\
\text { adrenal cortical tumour }\end{array}$ & 24 & 32 & 16 \\
\hline Female-to-male ratio & $1.4-1$ & 0.7-1 & $1.9-1$ & $2.2-1$ \\
\hline Age (mean/range) (year) & $53(1.3-84)$ & $54(31-78)$ & $\begin{array}{l}27 \text { (new born-77) bimodal } \\
\text { age distribution. In first } \\
\text { and third decades }\end{array}$ & $51(20-72)$ \\
\hline Side (right-to-left ratio) & $2.1-1$ & $2.4-1$ & $1.1-1$ & $1-1$ \\
\hline Size (mean/range) $(\mathrm{mm})$ & $63(4-400)$ & $75(10-200)$ & $99(24-380)$ & $88(2-160)$ \\
\hline Weight $(\mathrm{g})$ & $49(4-6000)$ & $417(7-2900)$ & $1189(49-10,000)$ & $168(3-626)$ \\
\hline Diseases association & Chronic diseases & - & - & Tuberous sclerosis \\
\hline Symptomatic/asymptomatic & $1.6-1$ & $0.6-1$ & $1.7-1$ & $2.2-1$ \\
\hline
\end{tabular}


fat cells containing phosphatides in the cytoplasm and eccentrically placed nuclei. Two cases of adrenal hibernomas were reported in the English literature. The first case of adrenal hibernoma was reported by Schwartz and Wasson in 2003 (Schwartz \& Wasson 2003). The tumour was associated with myelolipoma. The other case was reported by Val-Bernal and coworkers in 2013 (Val-Bernal et al. 2013). The patient also had a cortical adenoma producing primary hyperaldosteronism. Both are small tumours (11 $\mathrm{mm}$ and $17 \mathrm{~mm}$, respectively), asymptomatic and detected in associated with other benign adrenal tumours.

\section{Adrenocortical tumours with fat component}

Adrenal cortical adenoma is the most common tumour in the adrenal gland (Lam 1992). Myelolipomatous changes are common. On the other hand, lipomatous changes without bone marrow component are not frequently reported. Seven adrenal cortical adenomas with extensive area of adipose tissue have been described in the literature. They have been labelled as adrenal cortical adenoma with fat component (Sato et al. 1995), adenoma with lipomatous metaplasia (Papotti et al. 1996), adrenal cortical extensive fat cell metaplasia (Feldberg et al. 1996) and lipoadenoma (Mylarappa et al. 2014, Uriev et al. 2014, Luo et al. 2015). In addition, Montone and coworkers have reported 2 cases of adrenocortical neoplasm with uncertain malignant potential having separate areas of myelolipomatous and lipomatous metaplasia (Montone et al. 2009). Similar to conventional adenomas, majority of these tumours were reported in female patients; only 2 cases were reported in male patients.

Adrenal oncocytoma is an adrenal cortical tumour consisting entirely or predominately of cells with dense eosinophilic cytoplasm. Four cases have been reported to contain fat. They were benign on clinical follow-up (Lin et al. 1998, Rosenkrantz et al. 2010). Two of these cases were asymptomatic and two presented with abdominal pain.

There are 3 adrenocortical carcinoma reported to be having a component of adipose tissue (Izumi et al. 2003, Heye et al. 2005, Egbert et al. 2010). The tumours were noted in left adrenal, functional and in male patients. One of them is a myxoid variant of adrenocortical carcinoma (Izumi et al. 2003).

\section{Other primary adrenal tumours with fat component}

Fat have been reported in cavernous haemangioma (Termote et al. 2007) and pheochromocytoma (Ramsay et al. 1987).

\section{Conclusion}

Adrenal lipomatous tumour is uncommon. Myelolipomas is the predominant type but various types of lipomatous adrenal gland tumours such as lipomas, teratoma, angiomyolipoma, and so forth are increasingly being reported. This group of tumours are often benign and non-functional. Table 6 presented the key features of the common adrenal lipomatous tumours showing that there are subtle differences between them. Surgery is recommended for tumours that are symptomatic, hormonally active and presenting with complications. It is important to recognize the features of this group of lipomatous tumours in the adrenal gland as they are being detected on increasing incidence as a result of the wide-spread use of modern imaging modalities.

\section{Declaration of interest}

The authors declare that there is no conflict of interest that could be perceived as prejudicing the impartiality of this review.

\section{Funding}

This research did not receive any specific grant from any funding agency in the public, commercial or not-for-profit sector.

\section{References}

Akamatsu H, Koseki M, Nakaba H, Sunada S, Ito A, Teramoto S \& Miyata M 2004 Giant adrenal myelolipoma: report of a case. Surgery Today 34 283-285. (doi:10.1007/s00595-003-2682-4)

Arnold J 1866 Ein Be itrag zu der feiner Struktur und dem Chemismus der Nebennieren. Virchows Archiv 35 64-107. (doi:10.1007/BF01979887)

Au WY, Tam PC, Ma SK \& Lam KY 2000 Giant myelolipoma in a patient with thalassemia intermedia. American Journal of Hematology 65 265-266. (doi:10.1002/1096-8652(200011)65:3<265::AIDAJH18>3.0.CO;2-H)

Avinoach I, Robinson CR, Avinoah E \& Peiser J 1989 Adrenal lipoma: a rare tumour of the adrenal gland. Histopathology 15 195-196. (doi:10.1111/j.1365-2559.1989.tb03067.x)

Barman S, Mandal KC \& Mukhopadhyay M 2014 Adrenal myelolipoma: an incidental and rare benign tumor in children. Journal of Indian Association of Pediatric Surgeons 19 236-238. (doi:10.4103/09719261.142019)

Bedri S, Erfanian K, Schwaitzberg S \& Tischler AS 2002 Mature cystic teratoma involving adrenal gland. Endocrine Pathology 13 59-64. (doi:10.1385/EP:13:1:59)

Bhatia V, Sharma S, Sood S, Mardi K \& Venkat B 2016 Case 231: retroperitoneal adrenal teratoma presenting as trichoptysis. Radiology 280 317-321. (doi:10.1148/radiol.2016140459)

Bhatti A, Al-Hindi H, Azzam A, Amin T \& Abu-Zaid A 2013 Mature (benign) cystic retroperitoneal teratoma involving the left adrenal gland in a 22-year-old male: a case report and literature review. Case Reports in Oncological Medicine 2013 610280. (doi:10.1155/ 2013/610280)

Bishop E, Eble JN, Cheng L, Wang M, Chase DR, Orazi A \& O'Malley DP 2006 Adrenal myelolipomas show nonrandom X-chromosome

Published by Bioscientifica Ltd. 
inactivation in hematopoietic elements and fat: support for a clonal origin of myelolipomas. American Journal of Surgical Pathology $\mathbf{3 0}$ 838-843. (doi:10.1097/01.pas.0000202044.05333.17)

Büttner A 1999 Lipoma of the adrenal gland. Pathology International 49 1007-1009. (doi:10.1046/j.1440-1827.1999.00966.x)

Caliumi C, De Toma G, Bossini A, Cianci R, Bosman C, Genuardi M, Cerci S \& Letizia C 2004 A rare combination consisting of aldosteroneproducing adenoma and adrenal myelolipoma in a patient with heterozygosity for retinoblastoma (RB) gene. Journal of the ReninAngiotensin-Aldosterone System 5 45-48. (doi:10.3317/jraas.2004.008)

Castillo OA, Vitagliano G, Villeta M, Arellano L \& Santis O 2006 Laparoscopic resection of adrenal teratoma. Journal of the Society of Laparoendoscopic Surgeons 10 522-524. (available at:https://www.ncbi. nlm.nih.gov/pmc/articles/PMC3015770/)

Castillo OA, Vitagliano G, Cortes O, Sánchez-Salas R \& Arellano L 2007 Laparoscopic adrenalectomy for adrenal myelolipoma. Archivos Españoles de Urología 60 217-221. (doi:10.4321/s0004-06142007000200022)

Chakraborty PP, Bhattacharjee R, Mukhopadhyay P \& Chowdhury S 2016 Bilateral adrenal myelolipoma in Cushing's disease: a relook into the role of corticotropin in adrenal tumourigenesis. BMJ Case Reports 2016 bcr2016214965. (doi:10.1136/bcr-2016-214965)

Chang KC, Chen PI, Huang ZH, Lin YM \& Kuo PL 2002 Adrenal myelolipoma with translocation $(3 ; 21)(\mathrm{q} 25 ; \mathrm{p} 11)$. Cancer Genetics and Cytogenetics 134 77-80. (doi:10.1016/S0165-4608(01)00592-1)

Chee Kong CH, Mohamed Rose I, Singam P, Eng Hong G, Boon Cheok L \& Zainuddin ZM 2010 Angiomyolipoma of the adrenal gland: a case report. Iranian Red Crescent Medical Journal 12 489-491. (available at:http://ircmj.com/302.fulltext)

Ciftci I, Cihan T, Koksal Y, Ugras S \& Erol C 2013 Giant mature adrenal cystic teratoma in an infant. Acta Informatica Medica 21 140-141. (doi:10.5455/aim.2013.21.140-141)

D’Antonio A, Caleo A, Caleo O, De Dominicis G \& Boscaino A 2009 Monotypic epithelioid angiomyolipoma of the adrenal gland: an unusual site for a rare extrarenal tumor. Annals of Diagnostic Pathology 13 347-350. (doi:10.1016/j.anndiagpath.2009.02.010)

Egbert N, Elsayes KM, Azar S \& Caoili EM 2010 Computed tomography of adrenocortical carcinoma containing macroscopic fat. Cancer Imaging 10 198-200. (doi:10.1102/1470-7330.2010.0029)

Elsayes KM, Narra VR, Lewis JS Jr \& Brown JJ 2005 Magnetic resonance imaging of adrenal angiomyolipoma. Journal of Computer Assisted Tomography 29 80-82. (doi:10.1097/01.rct.0000152863.97865.47)

Ersoz S, Kucuk H, Mungan S, Turgutalp H, Imamoglu M \& Kosucu P 2011 Neurocytoma arising in an adrenal gland mature teratoma. Fetal and Pediatric Pathology 30 275-279. (doi:10.3109/15513815.201 1.572955)

Feldberg E, Guy M, Eisenkraft S \& Czernobilsky B 1996 Adrenal cortical adenoma with extensive fat cell metaplasia. Pathology, Research and Practice 192 62-65. (doi:10.1016/S0344-0338(96)80132-4)

Feng C, Jiang H, Ding Q \& Wen H 2013 Adrenal myelolipoma: a mingle of progenitor cells? Medical Hypotheses 80 819-822. (doi:10.1016/j. mehy.2013.03.021)

Gershuni VM, Bittner JG 4th, Moley JF \& Brunt LM 2014 Adrenal myelolipoma: operative indications and outcomes. Journal of Laparoendoscopic \& Advanced Surgical Techniques 24 8-12. (doi:10.1089/lap.2013.0411)

Ghavamian R, Pullman JM \& Menon M 1998 Adrenal lipoma: an uncommon presentation of the incidental asymptomatic adrenal mass. British Journal of Urology 82 136-137. (doi:10.1046/ j.1464-410x.1998.00711.x)

Gierke E 1905 Uber knochenmarkesgewebe in der nebehnierre. Beitrage Zur Pathologischen Anatomie 7 311-325.

Godara R, Vashist MG, Singla SL, Garg P, Sen J, Mathur SK \& Gupta A 2007 Adrenal angiomyolipoma: a rare entity. Indian Journal of Urology 23 319-320. (doi:10.4103/0970-1591.33734)

Goldenberg A, Rager J, Szczurek L, Sandau RL \& Neff M 2011 Transabdominal laparoscopic adrenalectomy of a large adrenal lipoma: a case report and review of literature. International Journal of Surgery Case Reports 2 172-174. (doi:10.1016/j.ijscr.2011.05.004)

Goswami A, Sharma A, Khullar R, Soni V, Baijal M \& Chowbey P 2014 A case report and review of literature. Journal of Minimal Access Surgery 10 213-215. (doi:10.4103/0972-9941.141531)

Gunay LM, Bas KK \& Uygur MC 2011 Primary lipoma of the adrenal gland. American Surgeon 77 1265-1267.

Gupta M, Sood D \& Singh A 2009 Adrenal lipoma complicated by perinephric abscess. Urology Journal 6162.

Hancock E, Tomkins S, Sampson J \& Osborne J 2002 Lymphangioleiomyomatosis and tuberous sclerosis. Respiratory Medicine 96 7-13. (doi:10.1053/rmed.2001.1206)

Hafeez Bhatti AB, Dar FS \& Pervez M 2013 Adrenal angiomyolipoma. Journal of the College of Physicians and Surgeons Pakistan 23 663-664. (available at:https://jcpsp.pk/archive/2013/Sep2013/14.pdf)

Hasan M, Siddiqui F \& Al-Ajmi M 2008 FNA diagnosis of adrenal myelolipoma: a rare entity. Diagnostic Cytopathology 36 925-926. (doi:10.1002/dc.20941)

Heye S, Woestenborghs H, Van Kerkhove F \& Oyen R 2005 Adrenocortical carcinoma with fat inclusion: case report. Abdominal Imaging 30 641-643. (doi:10.1007/s00261-004-0281-5)

Hsu SW, Shu K, Lee WC, Cheng YT \& Chiang PH 2012 Adrenal myelolipoma: a 10-year single-center experience and literature review. Kaohsiung Journal of Medical Sciences 28 377-382. (doi:10.1016/j.kjms.2012.02.005)

Hu H \& Xi X 2012 Giant adrenal angiomyolipoma. Journal of Clinical Endocrinology and Metabolism 97 3835-3836. (doi:10.1210/jc.20122319)

Hui JPK, Luk WH, Siu CW \& Chan JCS 2004 Teratoma in the region of an adrenal gland in a 77-year-old man. Journal of Hong Kong College of Radiologists 7 206-209. (available at:www.hkjr.org/system/ files/\%252Fhome/hkjrorg/upload_file/v7n4_teratoma.pdf)

Ide H, Terado Y, Nakagawa T, Saito K, Kamiyama Y, Muto S, Okada H, Imamura T \& Horie S 2007 Incidentally discovered adrenal myelolipoma associated with hyperthyroidism. International Journal of Clinical Oncology 12 379-381. (doi:10.1007/s10147-007-0662-1)

Izumi M, Serizawa H, Iwaya K, Takeda K, Sasano H \& Mukai K 2003 A case of myxoid adrenocortical carcinoma with extensive lipomatous metaplasia. Archives of Pathology and Laboratory Medicine $\mathbf{1 2 7}$ 227-230.

Jain D, Chopra P \& Sharma A 2012 Adrenal lipoma with hemorrhage: a cause of abdominal pain. Urology Journal 9 721-724. (available at:http:// www.urologyjournal.org/index.php/uj/article/viewFile/1807/698)

James J, Dhillon GS, Blewett CJ, Halldorsson A \& Cecalupo AJ 2009 A large adrenal teratoma in a neonate. American Surgeon 75 347-349.

Jung SI, Kim SO, Kang TW, Kwon DD, Park K \& Ryu SB 2007 Bilateral adrenal myelolipoma associated with hyperaldosteronism: report of a case and review of the literature. Urology 1223 e11-e13. (doi:10.1016/j.urology.2007.09.046)

Kale G, Pelley EM \& Davis DB 2015 Giant myelolipomas and inadvertent bilateral adrenalectomy in classic congenital adrenal hyperplasia. Endocrinology, Diabetes and Metabolism Case Reports 2015 150079. (doi:10.1530/edm-15-0079)

Kaneko N, Kubota Y, Nakada T, Sasagawa I, Yaguchi H \& Suzuki H 2000 Dermoid cyst in the adrenal gland. Urologia Internationalis $\mathbf{6 4}$ 104-107. (doi:10.1159/000030501)

Kapetanakis S, Drygiannakis I, Tzortzinis A, Papanas N \& Fiska A 2011 A giant adrenal lipoma presenting in a woman with chronic mild postprandial abdominal pain: a case report. Journal of Medical Case Reports 5 136. (doi:10.1186/1752-1947-5-136)

Kenney PJ, Wagner BJ, Rao P \& Heffess CS 1998 Myelolipoma: CT and pathologic features. Radiology 208 87-95. (doi:10.1148/ radiology.208.1.9646797)

Khong PL, Lam KY, Ooi CG, Liu MJ \& Metreweli C 2002 Mature teratomas of the adrenal gland: imaging features. Abdominal Imaging 27 347-350. (doi:10.1007/s00261-001-0106-8) 
Kim JY, Cho YZ, Lee KW, Lim DM, Park KY \& Kim BJ 2011 A case of adrenal teratoma. Endocrinology and Metabolism 26 272-275. (doi:10.3803/EnM.2011.26.3.272)

Kulis T, Knezevic N, Pekez M, Kastelan D, Grkovic M \& Kastelan Z 2012 Laparoscopic adrenalectomy: lessons learned from 306 cases. Journal of Laparoendoscopic and Advanced Surgical Techniques A 22 22-26. (doi:10.1089/lap.2011.0376)

Kumar S, Jayant K, Prasad S, Agrawal S, Parma KM, Roat R \& Kumar K 2015 Rare adrenal gland emergencies: a case series of giant myelolipoma presenting with massive hemorrhage and abscess. Nephro-urology Monthly 7 e22671. (doi:10.5812/numonthly.26309)

Kwazneski D II, Merrill M, Young J \& Sell H Jr 2016 Angiomyolipoma and malignant PEComa: discussion of two rare adrenal tumors. Case Reports in Oncological Medicine 2016 article ID 5204092. (doi:10.1155/2016/5204092)

Lam KY 1992 Adrenal tumours in Chinese. Virchows Archiv 421 13-16. (doi:10.1007/BF01607133)

Lam KY \& Lo CY 1999 Teratoma in the region of adrenal gland: a unique entity masquerading as lipomatous adrenal tumor. Surgery 126 90-94. (doi:10.1067/msy.1999.98924)

Lam KY \& Lo CY 2001 Adrenal lipomatous tumours: a 30 year clinicopathological experience at a single institution. Journal of Clinical Pathology 54 707-712. (doi:10.1136/jcp.54.9.707)

Lam KY, Chan AC \& Ng IO 1997 Giant adrenal lipoma: a report of two cases and review of literature. Scandinavian Journal of Urology and Nephrology 31 89-90. (doi:10.3109/00365599709070308)

Lam AKY, Chuah KL, de Pinieux G, Fisher C \& Lack E 2017 Mesenchymal and stromal tumours. In World Health Organization Classification of Tumours of Endocrine Organs Tumours of the Adrenal Gland, 4th edition, Chapter 4.5, p 31. Lyon, France: IARC Press.

Lamont JP, Lieberman ZH \& Stephens JS 2002 Giant adrenal myelolipoma. American Surgeon 68 392-394.

Lane BR, Aydin H, Danforth TL, Zhou M, Remer EM, Novick AC \& Campbell SC 2008 Clinical correlates of renal angiomyolipoma subtypes in 209 patients: classic, fat poor, tuberous sclerosis associated and epithelioid. Journal of Urology 180 836-843. (doi:10.1016/j.juro.2008.05.041)

Lange HP 1966 Lipoma of the adrenal gland simulating the signs of phaeochromocytoma. German Medical Monthly 11 190-192.

Li Y, Zhong Z \& Zhao X 2011 Primary mature teratoma presenting as an adrenal tumor in a child. Urology 78 689-691. (doi:10.1016/j. urology.2010.12.022)

Li H, Zhao T, Wei Q, Yuan H, Cao D, Shen P, Liu L, Zeng H \& Chen N 2015 a Laparoscopic resection of a huge mature cystic teratoma of the right adrenal gland through retroperitoneal approach: a case report and literature review. World Journal of Surgical Oncology 13 318. (doi:10.1186/s12957-015-0734-z)

Li S, Li H, Ji Z, Yan W \& Zhang Y 2015b Primary adrenal teratoma: clinical characteristics and retroperitoneal laparoscopic resection in five adults. Oncology Letters 10 2865-2870. (doi:10.3892/ ol.2015.3701)

Lin BT, Bonsib SM, Mierau GW, Weiss LM \& Medeiros LJ 1998 Oncocytic adrenocortical neoplasms: a report of seven cases and review of the literature. American Journal of Surgical Pathology 22 603-614. (doi:10.1097/00000478-199805000-00012)

Lu HS, Gan MF, Chen HS \& Huang SQ 2008 Adrenal myelolipoma within myxoid cortical adenoma associated with Conn's syndrome. Journal of Zhejiang University Science B 9 500-505. (doi:10.1631/jzus. A071361)

Luo J, Chen L, Wen Q, Xu L, Chu S, Wang W, Alnemah MM \& Fan S 2015 Lipoadenoma of the adrenal gland: report of a rare entity and review of literature. International Journal of Clinical and Experimental Pathology 8 9693-9697. (available at:https://www.ncbi.nlm.nih.gov/ pmc/articles/PMC4583971/)

Mardi K, Sharma S \& Sood S 2015 Mature cystic teratoma involving the left adrenal gland with complete colonic wall formation in a 24-year-old female: a rare case report. Clinical Cancer Investigation Journal 4 47-49. (doi:10.4103/2278-0513.149041)

Maziak DE, Kesten S, Rappaport DC \& Maurer J 1996 Extrathoracic angiomyolipomas in lymphangioleiomyomatosis. European Respiratory Journal 9 402-405. (doi:10.1183/09031936.96.09030402)

Matthyssens LE, Creytens D \& Ceelen WP 2015 Retroperitoneal liposarcoma: current insights in diagnosis and treatment. Frontiers in Surgery 2 4. (doi:10.3389/fsurg.2015.00004)

McMillan A \& Horwich A 1987 Malignant teratoma presenting with an adrenal mass. Clinical Radiology 38 327-328. (doi:10.1016/S00099260(87)80088-0)

Milathianakis KN, Farfarelos CD, Mpogdanos IM \& Karamanolakis DK 2002 Giant lipoma of the adrenal gland. Journal of Urology 1671777. (doi:10.1016/S0022-5347(05)65198-1)

Mitsui Y, Yasumoto H, Hiraki M, Arichi N, Ishikawa N, Harada Y, Maruyama R \& Shiina H 2014 Coordination of bone morphogenetic protein 2 (BMP2) and aberrant canonical Wnt/ $\beta$-catenin signaling for heterotopic bone formation in adrenal myelolipoma: a case report. Canadian Urological Association Journal 8 E104-E107. (doi:10.5489/cuaj.1610)

Montone KT, Rosen M, Siegelman ES, Fogt F \& Livolsi VA 2009 Adrenocortical neoplasms with myelolipomatous and lipomatous metaplasia: report of 3 cases. Endocrine Practice 15 128-133. (doi:10.4158/ep.15.2.128)

Motta I, Boiocchi L, Delbini P, Migone De Amicis M, Cassinerio E, Dondossola D, Rossi G \& Cappellini MD 2016 A giant adrenal myelolipoma in a beta-thalassemia major patient: does ineffective erythropoiesis play a role? American Journal of Hematology 91 1281-1282. (doi:10.1002/ajh.24446)

Mylarappa P, Pathade A, Javali T \& Ramesh D 2014 Virilizing lipoadenoma of the adrenal gland in a pre-pubertal girl: a rare case. Indian Journal of Urology 30 219-221. (doi:10.4103/09701591.126910)

Nadeem M, Ather MH, Sulaiman MN \& Pervez S 2015 'Looks can be deceiving': adrenal teratoma causing diagnostic difficulty. Urology Case Reports 2015 232591. (doi:10.1155/2015/232591)

Narla SL, Jacob S, Kurian A \& Parameswaran A 2016 Primary mature cystic teratoma with carcinoid mimicking an adrenal tumor: report of a rare association and review of literature. Indian Journal of Pathology and Microbiology 59 200-202. (doi:10.4103/03774929.182012)

Oberling C 1929 Les formations myelolipomateuses. Bulletin of the Association of France Cancer 18 234-246.

Oguzkurt P, Ince E, Temiz A, Demir S, Akabolat F \& Hicsonmez A 2009 Prenatal diagnosis of a mass in the adrenal region that proved to be a teratoma. Journal of Pediatric Hematology-Oncology 31 350-351. (doi:10.1097/MPH.0b013e318190d765)

Ong K, Tan KB \& Putti TC 2007 Myelolipoma within a non-functional adrenal cortical adenoma. Singapore Medical Journal 48 e200-e202.

Papotti M, Sapino A, Mazza E, Sandrucci S, Volante M \& Bussolati G 1996 Lipomatous changes in adrenocortical adenomas: report of two cases. Endocrine Pathology 7 223-228. (doi:10.1007/bf02739925)

Patel RD, Vanikar AV \& Modi PR 2011 Giant lipoma of the adrenal gland: a case report. Journal of Medical Case Reports 578. (doi:10.1186/1752-1947-5-78)

Polo JL, Villarejo PJ, Molina M, Yuste P, Menéndez JM, Babé J \& Puente S 2004 Giant mature cystic teratoma of the adrenal region. American Journal of Roentgenology 183 837-838. (doi:10.2214/ ajr.183.3.1830837)

Prinz RA, Brooks MH, Churchill R, Graner JL, Lawrence AM, Paloyan E \& Sparagana M 1982 Incidental asymptomatic adrenal masses detected by computed tomographic scanning. Is operation required? JAMA 248 701-704. (doi:10.1001/jama.248.6.701)

Puri R, Thandassery RB, Choudhary NS, Kotecha H, Misra SR, Bhagat S, Paliwal M, Madan K, Saraf N, Sarin H, et al. 2015 Endoscopic ultrasound-guided fine-needle aspiration of the adrenal glands: 
analysis of 21 patients. Clinical Endoscopy 48 165-170. (doi:10.5946/ ce.2015.48.2.165)

Ramsay JA, Asa SL, van Nostrand AW, Hassaram ST \& de Harven EP 1987 Lipid degeneration in pheochromocytomas mimicking adrenal cortical tumors. American Journal of Surgical Pathology 11 480-486. (doi:10.1097/00000478-198706000-00009)

Ratkal JM, Shaik NJ, Salia D \& Choukimath SM 2015 Rare primary retroperitoneal teratoma masquerading as adrenal incidentaloma. African Journal of Urology 21 96-99. (doi:10.1016/j.afju.2014.11.008)

Rodríguez-Calvo MS, Suárez-Peñaranda JM, Alvarez MT, Muñoz JI, OrtizRey JA \& Concheiro L 2007 Adrenal lipomas: incidental autopsy findings. Pathology International 57 751-753. (doi:10.1111/ j.1440-1827.2007.02166.x)

Rosenkrantz AB, Do RK \& Hajdu CH 2010 Imaging appearance of bulk fat within an oncocytic adrenocortical neoplasm, a rare and potentially malignant tumour. British Journal of Radiology $\mathbf{8 3}$ e204-e207. (doi:10.1259/bjr/50022555)

Sato N, Watanabe Y, Saga T, Mitsudo K, Dohke M \& Minami K 1995 Adrenocortical adenoma containing a fat component: CT and MR image evaluation. Abdominal Imaging 20 489-490. (doi:10.1007/ BF01213281)

Sazuka T, Imamoto T, Utsumi T, Yanagisawa M, Nakamura K, Suyama T, Sakamoto S, Kawamura K, Nihei N \& Ichikawa T 2013 Angiomyolipoma in the adrenal region: adrenalectomy converted from laparoscopic to open laparotomy case. Japanese Journal of Endourology 26 135-137. (doi:10.11302/jsejje.26.13)

Schwartz BF \& Wasson L 2003 Hibernoma arising from the adrenal gland. Urology 61 1035. (doi:10.1016/S0090-4295(02)02586-4)

Settakorn J, Sirivanichai C, Rangdaeng S \& Chaiwun B 1999 Fineneedle aspiration cytology of adrenal myelolipoma: case report and review of the literature. Diagnostic Cytopathology 21 409-412. (doi:10.1002/(sici)1097-0339(199912)21:6<409::aid-dc9>3.0.co;2-a)

Shah S \& Bhatti SU 2009 Primary adrenal lipoma. Journal of the College of Physicians and Surgeons Pakistan 19 450-451. (available at:https:// jcpsp.pk/archive/2009/Jul2009/14.pdf)

Sharma MC, Gill SS, Kashyap S, Nabi G \& Mishra MC 1998 Adrenal lipoma: a case report. Urologia Internationalis $60245-247$. (doi:10.1159/000030265)

Shenoy VG, Thota A, Shankar R \& Desai MG 2015 Adrenal myelolipoma: controversies in its management. Indian Journal of Urology 31 94-101. (doi:10.4103/0970-1591.152807)

Shrestha MK \& Lalchan S 2010 Adrenal gland teratoma in a 40-year-old woman. Nepal Medical College Journal 12 201-202. (available at:http://nmcth.edu/images/gallery/Case\%20Report/vVvVkmk_ shrestha.pdf)

Shumaker NR, Rochman CM, Legallo RD, Northup CJ \& Hanks JB 2008 Incidentally identified adrenal lipoma: case report and review of related literature. Endocrine Practice 14 209-212. (doi:10.4158/ ep.14.2.209)

Singaporewalla RM, Thamboo TP, Rauff A, Cheah WK \& Mukherjee JJ 2009 Acute abdominal pain secondary to retroperitoneal bleeding from a giant adrenal lipoma with review of literature. Asian Journal of Surgery 32 172-176. (doi:10.1016/ S1015-9584(09)60390-0)

Soveid M \& Rais-Jalali GA 2016 Seventeen alpha-hydroxylase deficiency associated with absent gonads and myelolipoma: a case report and review of literature. Iranian Journal of Medical Sciences 41 543-547. (available at:https://www.ncbi.nlm.nih.gov/pmc/articles/ PMC5106571/)

Su HC, Huang X, Zhou WL, Dai J, Huang BX, Cao WL \& Sun FK 2014 Pathologic analysis, diagnosis and treatment of adrenal myelolipoma. Canadian Urological Association Journal 8 E637-E640. (doi:10.5489/cuaj.422)

Sutter R, Boehler A \& Willmann JK 2007 Adrenal angiomyolipoma in lymphangioleiomyomatosis. European Radiology 17 565-566. (doi:10.1007/s00330-006-0206-5)

Tamidari H, Mishra AK, Gupta S \& Agarwal A 2006 Catecholamine secreting adrenal myelolipoma. Indian Journal of Medical Sciences $\mathbf{6 0}$ 331-333. (doi:10.4103/0019-5359.26611)

Tang DD, Zhang XS, Hao ZY, Zhou J \& Liang CZ 2014 A giant primary retroperitoneal mature cystic teratoma in right adrenal region in a 39-year-old female. International Journal of Clinical and Experimental Medicine 7 1611-1613. (available at:http://www.ijcem.com/files/ ijcem0000632.pdf)

Termote B, Verswijvel G \& Palmers Y 2007 Fat containing adrenal cavernous haemangioma: CT and MRI findings. JBR-BTR 90 516-518.

Thway K \& Fisher C 2015 PEComa: morphology and genetics of a complex tumor family. Annals of Diagnostic Pathology 19 359-368. (doi:10.1016/j.anndiagpath.2015.06.003)

Udupa S, Usha M, Visweswara RN \& Desai MG 2012 Left-sided giant adrenal myelolipoma secreting catecholamine. Indian Journal of Pathology and Microbiology 55 389-391. (doi:10.4103/03774929.101755)

Uriev L, Maslovsky I, Ben-Dor D \& Barak F 2014 Adrenal lipoadenoma. Pathology Discovery 2 2. (doi:10.7243/2052-7896-2-2)

Val-Bernal JF, Azueta A, Ortiz-Rivas LA, Fuentes J \& Ballestero R 2013 Incidental lipoma-like hibernoma arising from the adrenal gland: a well-differentiated liposarcoma mimicker. Pathology Research and Practice 209 812-816. (doi:10.1016/j.prp.2013.07.009)

Yamada S, Tanimoto A, Wang KY, Ding Y, Guo X, Shimajiri S, Sasano H \& Sasaguri Y 2011 Non-functional adrenocortical adenoma: a unique case of combination with myelolipoma and endothelial cysts. Pathology Research and Practice 207 192-196. (doi:10.1016/j. prp.2010.07.008)

Yang Y, Ye LY, Yu B, Guo JX, Liu Q \& Chen Y 2015 Two case reports of bilateral adrenal myelolipomas. World Journal of Clinical Cases $\mathbf{3}$ 853-860. (doi:10.12998/wjcc.v3.i9.853)

Yener O \& Ozçelik A 2011 Angiomyolipoma of the right adrenal gland. ISRN Surgery 2011 article ID 102743. (doi:10.5402/2011/102743)

Yin L, Teng J, Zhou Q, Liu Y, Yao Y, Gao Y, Cui X, Ren J \& Xu D 2014 A 10-year single-center experience with surgical management of adrenal myelolipoma. Journal of Endourology 28 252-255. (doi:10.1089/end.2013.0283)

Zattoni D, Balzarotti R \& Rosso R 2015 The management of bilateral myelolipoma: case report and review of the literature. International Journal of Surgery Case Reports 12 31-36. (doi:10.1016/j. ijscr.2015.04.021)

Zhao J, Sun F, Jing X, Zhou W, Huang X, Wang H, Zhu Y, Yuan F \& Shen Z 2014 The diagnosis and treatment of primary adrenal lipomatous tumours in Chinese patients: a 31-year follow-up study. Canadian Urological Association Journal 8 E132-E136. (doi:10.5489/cuaj.977)

Received in final form 26 January 2017

Accepted 31 January 2017

Accepted Preprint published online 31 January 2017 http://erc.endocrinology-journals.org DOI: 10.1530/ERC-16-0564
(C) 2017 Society for Endocrinology Printed in Great Britain
Published by Bioscientifica Ltd 